Theological Research • volume 5 (20I7) - P. 93-IO5

doi: http://dx.doi.org/Io.15633/thr.3303

Jason M. Wirth

Seattle University

\title{
Schelling and Luther
}

\section{Abstract}

Although it would be a stretch to consider FWJ Schelling a Lutheran, he shared some critical features of Luther's critical engagement with Catholicism. This essay engages this mutual confrontation, and then discusses the new horizon, what Schelling dubs the Johanine Church, the church for everyone and everything, that is the latent promise of the Lutheran (and Pauline) confrontation with the Petrine (or Catholic) Church. As such, this essay is an exercise in what Schelling called philosophical religion, a fruit of his late turn to positive philosophy.

\section{KeYwords}

FWJ Schelling, Martin Luther, philosophical religion, Deus absconditus 
He made darkness his covering.

(Psalms I8:II)

\section{i. Manifest Stupidity}

Schelling and Luther? In his curious book, Schelling versus Hegel, ${ }^{,}$John Laughland argues that Schelling died a sort of Catholic, having abandoned Hegel's idealism for "the creation and nature of God's action in reality" (svH, II5). As Schelling aged, his resistance waned, and he become increasingly religious. "To put it bluntly, in his old age Schelling got God" (svH, 37). Indeed, according to this account, in his senescence he reverted to a kind of incipient Catholicism while Hegel, still under the spell of Luther, "brought to a head the Protestant insistence [...] that 'truth must be verified by my own insight"' $(\mathrm{svH}, \mathrm{I} 43)$. Idealism had secured the noumenal ground of the Lutheran subject, but Schelling, through and through a critic of subjectivity, broke from it to return to a pre-modern conception of revelation and hence it was a welcome irony that "a Catholic priest read prayers over the Lutheran Schelling's open grave" (svH, I50).

Alas, texts, like the dead, have no rights! This interpretation makes it sound like the young Schelling had made a clean break into idealism, but, as he grew old and weary, the old ways crept back in, making him more and more reactionary until he collapsed into the very forces from which he originally distinguished himself.

Was Schelling an idealist Lutheran or a reactionary Catholic and, to a more contemporary sensibility, what difference would it make since these are the parts of Schelling that we pass over in a kind of embarrassed and condescending silence? As a point of fact, Schelling was neither a reborn Catholic nor a tenacious Protestant, although it is clear that he maintained a deep and radical appreciation of Luther. But more fundamentally, such discussions imply that we have a clear idea of what we mean by God and religion, as if we have figured them out, affirmed or debunked them, and than moved on to less awkward enterprises. In his famous inaugural Berlin lectures, Schelling provocatively suggested that it makes no sense to imagine that we can go beyond

I J. Laughland, Schelling versus Hegel: From German Idealism to Christian Metaphysics, Aldershot-Burlington 2007, [henceforth: svH]. 
Christianity because that would imply that we know what we are talking about. He asked: "Have you even understood Christianity? How so, if a philosophy must first unlock its depths?"

This does not mean that Schelling had reverted to the old premodern game of deploying philosophy to marshal yet another apology to secure the empire of institutional Christianity. Despite the long and often dogmatically over-reaching history of Christian metaphysics, philosophy, misappropriating its energies on defending and promoting compulsory Christianity, still had not yet unearthed its latent promise. Just as Luther thought that God was truly in Scripture and in crucifixion but not therefore as wholly revealed but rather as hidden and secret, Schelling argued that God is latent in Christianity as its concealed enigma. The secret depths of Revelation had not been revealed in the public event of Revelation, depths which heretofore suggest that Revelation is more like a mystery religion (Geheimlehre) in which a few adepts entered into the mystery of its resolutely non-public secret.

Moreover, religion, left to its own devices, that is, to the husk of its historically revealed self-understanding, cannot access itself. One cannot be religious merely by being "religious," i.e., just by assenting to what is publically know of religious life. The key to religion's concealed depths is what Schelling dubbed philosophical religion and it in turn is wholly dependent on the event of positive philosophy. The latter is "toto caelo verschieden," diametrically, literally, by the whole extent of the heavens, opposed to traditional Christian philosophy and even offers for the first time the "true concept of religion" (PO, I48). Religion has been sealed, awaiting philosophy to unleash its power. Schelling did not advocate a Christianity that we have had, but rather a Christianity to come, a prophetic Christianity made possible by a new kind of philosophical thinking. Schelling was a kind of second John the Baptist, with a premonition (Ahnung) of another kind of future, a future rooted in the ongoing $\kappa \varepsilon \dot{v} \omega \sigma 1 \varsigma^{3}$ of a living God, "who comes out of itself through its own power and becomes other to itself in its unprethinkable being [der

2 "Habt ihr das Christentum den schon erkannt? Wie, wenn eine Philosophie erst seine Tiefen aufschlösse?" Schelling, Philosophie der Offenbarung I84I/42 [The Paulus Nachschrift], second, expanded edition, Hrsg. M. Frank, Frankfurt am Main I993, 97 [henceforth: Po].

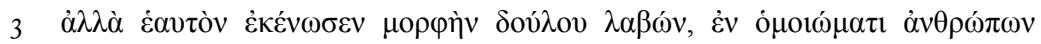

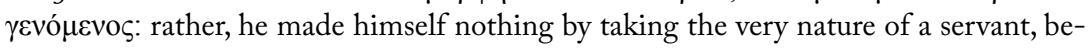
ing made in human likeness (Philippians 2:7, NIV). 
aus eigener Macht aus sich herausgeht, ein Anderes von sich in seinem unvordenklichen Sein wird]" (PO, I7O). Reason is beholden to the ongoing revelation of being such that being always remains unthought in its coming to be thought. Reason must navigate the non-reason of its ground and the unprethinkability (Unvordenklichkeit) of existence because the eternal beginning (der ewige Anfang) of reason is intractably hidden!

What are we to make of unreason at the heart of reason and hiddenness at the ground of all possible manifestation? This is only a problem if we assume that philosophy belongs wholly to the provenance of light. Why do we cede the madness of philosophy so quickly to the monolithic demands of sobriety? That is the stupidity-literally, the stupefaction- before the threat of divine madness and withdrawal that characterizes the Verstandesmensch. Strikingly anticipating Nietzsche's Birth of Tragedy, Nietzsche avant la lettre, the late Schelling speaks of the rational intoxication at the heart of human and divine creativity:

The mystery of true art is to be simultaneously mad and level-headed [wahnsinnig und besonnen], not in distinctive moments, but rather uno eodemque actu [altogether in a single act]. This is what distinguishes the Apollonian inspiration from the Dionysian. The highest task of art, which gleams before us like a miracle, is to present in the most conditioned and finite form an infinite content, which, so to speak, contests all form. God is in no way the mere antithesis of finitude; God is in no way that which can only be pleased in the infinite, but rather God appears precisely as the most artificial of beings [Wesen], seeking finitude and not resting until $\mathrm{He}$ has brought everything into the most finite form. ${ }^{4}$

The mystery of Christianity, far from its own historical self-understanding, is the Apollonian radiance of the universe, the cosmos as an unfolding poem. The stupidity of lopsidedly sober and reasonable thought, thought as the dull and anxiety-averse exercise of the Verstandesmensch's administration of the knowable, is more deeply revealed to be an evil urge to dominate the earth. The religious gesture, however, with its devotion to the hidden ground of the earth, finds its strength precisely in the capacity to become utterly vulnerable.

4 Urfassung der Philosophie der Offenbarung, two volumes, Hrsg. W. E. Ehrhardt, Hamburg 1992, p. 422 [henceforth: U]. 
In this sense, Schelling speaks in a Pauline fashion of unreasonableness (Unvernünftigkeit) at the heart of reason "with respect to the ways of human judgment as a stupidity [Torheit]. The most audacious of the apostles, Paul, [...] speaks of a divine stupidity, of the weakness of God, which is, however, as he says, stronger than all human strength. It is not given to everybody to grasp the deep irony in all divine ways of acting" (U, 420-42I).

Schelling's allusion to the audacity of Paul, who in I Corinthians calls himself a moron or fool for the Christ, ${ }^{5}$ is also a key to his appreciation of Luther. Paul earlier in the same epistle claims that "the stupidity of God is wiser than humans and the weakness of God is stronger than humans." ${ }^{6}$ The stupidity (Torheit, $\mu \omega \rho$ ós) of God, what itself ironically appears to the Verstandesmensch as merely moronic, is precisely what demonstrates the stupidity of the stupid: it is not me that is stupid, but rather that which I stupidly shun that is stupid. In other words, the stupidity of Verstandesmensch is too stupid to know that it is their normal knowledge and status quo religiosity that is stupid. When the stupidity of the status quo is revealed, they cannot see it and instead castigate the threats to the normal as stupid. They project their own "stupidity" on God because they cannot see divine stupidity.

This aspect of Pauline thought, which resonates deeply with Schelling and, as we shall see, Luther, is also the impressive focus of Stanislas Breton's study of Saint Paul, The Word and the Cross, which speaks of the shattering power of the "logos of the cross." Breton, too, takes up Paul's epistle, especially the passage at I Corinthians i:18: "The logos of the cross is folly [ $\mu \omega$ pía] for those who are perishing, but to the saved, it is the power of God." 7 The language of the cross, the meontic force of death rendered holy, the otherwise than being that comes to contest being, is, for Breton's reading of Paul, "the death of evidence" that is "the true beginning [...] God has chosen that which is not $(\mu \eta \dot{~}$

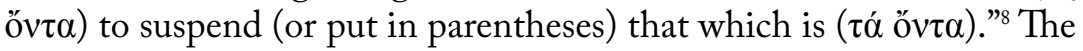
force of the $\mu \grave{\eta}$ òv, the otherwise than being, the logos of the cross as it

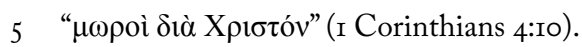

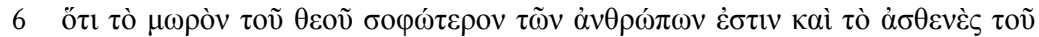

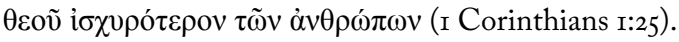

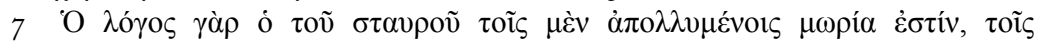

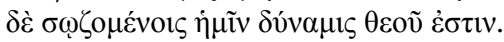

8 S. Breton, The Word and the Cross, trans. J. Porter, New York 2002, p. 8. 
supplants the domain of the Verstandesmensch and his and her prevailing orders of evidence, as well as the invidious consensus according to which we wage our wars of recognition, appears to those who cannot acknowledge this force as moronic, as the stupidity of $\mu \omega$ pía. Nonetheless, the power of radical or divine stupidity seeks to redeem the immense hold of human "stupidity."

\section{Hidden in Suffering (AbSConditum in PAssionibus)}

In the twenty-first thesis of his infamous Heidelberg Disputation of $1518,{ }^{9}$ Luther rejected a theology of glory for what he called, echoing Paul, a theology of the cross. This distinction is critical to our present discussion and at the heart of Schelling's esteem for Luther. A selfcongratulatory and proud theology, intoxicated by glory, takes itself very seriously, but in its inebriation, gets things backward, calling "evil good and good evil." Conversely, a "theology of the cross calls the thing what it actually is." Dying on the cross-akin to Paul's sojourn to Damascus-sets right side up what mere inebriation (and the Verstandesmensch's "stupidity") has first set upside down.

The Schwärmer, the swarms of Verstandesmenschen and priestly bureaucrats who pompously administer and promulgate God as manifest and known, invert and hence pervert what they think they are glorifying. Citing Paul's epistles to the Romans as well as the Corinthians, Luther chides these theologians and their ego-inebriated confidence in the manifest:

That person does not deserve to be called a theologian who looks upon the "invisible" things of God as though they were clearly "perceptible in those things which have actually happened." ${ }^{\text {זo }}$ This is apparent in the

9 All quotations from Martin Luther are from the widely available and canonical Concordia: The Lutheran Confessions - A Reader's Edition of the Book of Concord, second edition, ed. P. T. McCain, Saint Louis 2006.

Io Luther here cites Romans 1:20: "For since the creation of the world God's invisible qualities-his eternal power and divine nature- have been clearly seen, being understood from what has been made, so that people are without excuse" (NIV). He cross references this with I Corinthians I:2I-25: "For since in the wisdom of God the world through its wisdom did not know him, God was pleased through the foolishness of what was preached to save those who believe. Jews demand signs and Greeks 
example of those who were "theologians" and still were called "fools" by the Apostle in Romans I:22." (Thesis 19)

If the pseudo-theologians conflate the unmanifestable with the manifest, their folly restricts them from seeing their folly. Folly does not manifest itself as folly - that is part of its folly. To the stupid (the endless day of the Verstandesmensch), it is the benighted others who appear stupid and there is no way out from within this trap. Their selfimportant stupidity has to be crucified in order to become a fool for the Christ-it is not I who live but Christ who lives in me. Luther continues:

He deserves to be called a theologian, however, who comprehends the visible and manifest things of God seen through suffering and the cross. The manifest and visible things of God are placed in opposition to the invisible, namely, his human nature, weakness, foolishness. The Apostle in I Corinthians r:25 calls them the weakness and folly of God. Because men misused the knowledge of God through works, God wished again to be recognized in suffering, and to condemn "wisdom concerning invisible things" by means of "wisdom concerning visible things," so that those who did not honor God as manifested in his works should honor him as he is hidden in his suffering (absconditum in passionibus). As the Apostle says in I Corinthians I:21, "For since in the wisdom of God the world through its wisdom did not know him, God was pleased through the foolishness of what was preached to save those who believe." Now it is not sufficient for anyone, and it does him no good to recognize God in his glory and majesty, unless he recognizes him in the humility and shame of the cross. Thus God destroys the wisdom of the wise, as Isaiah 45:15 says, "Truly, You are a God who hides Yourself." (Thesis 20)

Hence Luther rails against the "completely puffed up, blinded, and hardened" wisdom that thinks that it "sees the invisible things of God

look for wisdom, but we preach Christ crucified: a stumbling block to Jews and foolishness to Gentiles, but to those whom God has called, both Jews and Greeks, Christ the power of God and the wisdom of God. For the foolishness of God is wiser than human wisdom, and the weakness of God is stronger than human strength" (NIV).

II "Although they claimed to be wise, they became fools" (NIV). 
in works as perceived by man" (thesis 22). Not knowing the cross and therefore not knowing God "hidden in suffering [absconditum in passionibus]," they pursue its opposite, becoming "puffed up" by "good works" (thesis 2I) and endlessly indulging in the bottomless thirst of desire (thesis 22). "Just as the love of money grows in proportion to the increase of the money itself, so the dropsy of the soul becomes thirstier the more it drinks" (thesis 22). Only the "deflation" of the cross and its hard won divine folly allow one to die to oneself and see that "works" belong to God, not oneself (thesis 2I). Folly has to be extirpated in order to encounter divine folly:

The remedy for curing desire does not lie in satisfying it, but in extinguishing it. In other words, he who wishes to become wise does not seek wisdom by progressing toward it but becomes a fool by retrogressing into seeking "folly." Likewise he who wishes to have much power, honor, pleasure, satisfaction in all things must flee rather than seek power, honor, pleasure, and satisfaction in all things. This is the wisdom, which is folly to the world. (Thesis 22)

As Marius Mjaaland articulates it in his thoughtful reexamination of Luther, The Hidden God: this is God's "hiddenness sub contrario" where "power is hiding in weakness, actions are biding in suffering, good is hiding in evil, etc." ${ }^{12}$ This is the first paradoxical manifestation of hiddenness: in what appears to command no glory, beyond all vainglory, power, and self-aggrandizement, one dis-covers the hidden glory of God.

In dis-covering the hidden glory of God, concealed in the inglorious and the ignominious, however, it does not follow that God is therefore revealed and is no longer deus absconditus. There is the hiddenness of the cross-a location where God can be found as absconded-but there is also an absolute and majestic hiddenness, which we can find powerfully in works like De servo arbitrio (I525). Opposed to the delusion that our will is free, there is the absolute sovereignty of the divine will, "whose ways and reasons are unsearchable" (HG, 68). Luther is clear about this as he attempts to avoid obscurantism while simultaneously distancing himself from Erasmus. This is the "most profound secret

I2 M. T. Mjaaland, The Hidden God: Luther, Philosophy, and Political Theology, Bloomington-Indianapolis 20I6, p. 42 [henceforth: HG]. 
of majesty, that is, "God hidden in majesty" (section 64). In brings them to what Schelling in the first draft of Die Weltalter called das Verstummen der Wissenschaft, the growing silent of science. ${ }^{13}$ Or as Luther memorably frames it: "It is here the hand is to be laid upon the mouth, it is here we are to reverence what lies hidden, to adore the secret counsels of the divine Majesty, and to exclaim with Paul, 'Who are you [...] that would contend with God?' (Romans 9:20)” (section 23).

Scriptures do not exhaust the hiddenness of God; in revealing God they also reveal the limit of all possible revelation. As Luther infamously proclaims: "God, and the Scripture of God, are two things; no less so than God, and the Creature of God" (section 3). Luther critically and consequentially distinguished between "God preached and God bidden: that is, between the word of God and God Himself. God does many things which He does not make known unto us in His word" (section 64). This is Paul's "wisdom hidden in a mystery" (sections 27,158 ).

The hidden God, deus absconditus, hides in the radical conversion of suffering as well as in the imponderable mystery of God's majesty. Yet, despite such majestic concealment, it remains no less hidden. It is revealed as hidden, only to become the majestic power of the absolutely hidden. Indeed, as Mjaaland contends, "the deus absconditus is hidden within yet beyond both the hiddenness revealed in the crucifixion and the hiddenness of majesty and sovereignty itself" (HG, IO6).

Deus absconditus, hidden in the revelation of its majestic hiddenness, is not so much a conclusion or a demonstration but rather Breton's "death of evidence" that is "the true beginning." It is at the heart of all images but in itself it has no possible image and emerges beyond image and in the destruction of those who drunkenly attach themselves to images. Mjaaland: "The notion of 'deus absconditus' is radically destructive, indeed, iconoclastic, when it comes to myths and images of God" (HG, 89). As such, it remains prior to all revelation, "older than beings and prior to their existence" ( $\mathrm{HG}, \mathrm{I33}$ ), much like Schelling who spoke of the ground of nature as the "abyss of the past" and an author

I3 "I would like, if it were not too immodest, to take this opportunity to say what I have so often felt... namely, how much closer I am than most people could conceive to that growing silent of science [Verstummen der Wissenschaft] which must necessarily emerge if we know how infinitely personal everything is, that it is impossible really to know anything." Die Weltalter in den Urfassungen von I8II und I8I3 (Nachlaßband), Hrsg. M. Schröter, Munich I946, p. Io3. 
who wrote in undecipherable hieroglyphics $(\mathrm{I} / 5,246)$. The deus absconditus is a kind of irreducible remainder, that, as such, remains "the indefinable condition for phenomenality by resisting the grasp of human reason" (HG, I3I). Schelling resonated with this Lutheran sensibilitycrucifixion as the price of resurrection into the wisdom of folly-as the price of admission for doing philosophy, which first demands wrenching it away from the clutches of the Verstandesmensch. In the Erlanger Vorlesungen (1820-2I), I4 Schelling counsels that those who would philosophize, those "who want to place themselves at the beginning point of a truly free philosophy, must abandon even God" (IPU, I8). One does not enter the space of philosophy just by signing up for a college course. It is exclusively for those who "had once left everything and who were themselves left by everything" and who, like Socrates contemplating his demise in the Phaedo, "saw themselves alone with the infinite: a great step which Plato compared to death" (IPU, I8-I9). Hence:

What Dante had written on the gate of the Inferno could also in another sense be the entrance into Philosophy: 'Abandon hope all you who enter here.' The one who wants truly to philosophize must let go of all hope, all desire, all Sebnsucht. They must want nothing, know nothing, feel themselves bare and poor. They must give up everything in order to gain everything. (IPU, I9)

This was Schelling's account of the spiritual crucifixion in order to enter the gate of philosophical study.

\section{After Luther}

Schelling resisted the inebriated arrogance of orthodoxy and did not associate Christianity with a doctrine (Lehre), but rather considered it a matter for thought (eine Sache) (sw II/4, 228). ${ }^{\text {I5 }}$ Schelling's lectures

I4 F.W.J. Schelling, Initia Philosophice Universa (I820-2I), Hrsg. H. Fuhrmans, Bonn I969 [henceforth: IPU].

I5 Citations follow the standard pagination, which adheres to the original edition established after Schelling's death by his son, Karl. It lists the division, followed by the volume, followed by the page number. Hence (I/I, I) would read, division one, volume one, page one. This pagination is preserved in Manfred Schröter's critical reorganization of this material. Schellings Sämtliche Werke, Hrsg. K. F. A. Schelling, 
on mythology and revelation explicitly did not seek to "establish any actual doctrine or any kind of speculative dogmatism for we will not in any way be dogmatic" $(\mathrm{II} / 4,3 \mathrm{O})$. At issue is not any institution's promulgation of any particular doctrine of revelation. "The matter for thought $[$ Sache $]$ of revelation is older than any dogma and we will simply occupy ourselves with the matter for thought and not with any of the various ways it has been subjectively conceived" (sw II/4, 30).

This did not mean that Schelling went to war against established or "understood" religion - he always remains respectful. This is nonetheless a radical genealogical retrieval of the very possibility and potency of religion. Schelling associated the historically domineering (universalizing by way of the sword) Catholic Church with Peter, and just as Peter wept tears of remorse for betraying Christ, one day the Catholic Church will do likewise. Although the Catholic Church possesses the mystery, they did not find it all that mysterious and were given to "abiding and constant domination." "19 Indeed, "the pope is the true antichrist" (PO, 318$)$ and the Petrine Church is "in the city" $(\mathrm{U}, 708)$, that is, is the Church of empire. Peter, the rock upon which Christian empire was built, had the evidence of the Christ, but he did not have the madness and folly of the hidden ground of the Christ. The husk of Christianity spread everywhere, but to find its enigmatic and majestic seed, one would have to leave the official city of manifest Christianity and, like the mystics and spiritual rebels, attempt to break through the existence of Christianity to the dark ground of Christianity. In a sense, Catholicism needed the death of God to be reborn into the folly of a radical Catholicism, grounded in the mystery of the hidden God.

If Peter is the official Church $\left(\mathrm{A}^{\mathrm{I}}\right)$ and the hold of the past and the tyranny of its historical evidence and forms, then the Pauline ChurchLuther's Church-is the bidden Church $\left(\mathrm{A}^{2}\right)(\mathrm{II} / 4,707)$, "external to the city [in der Vostadt]" (U, 708). Just as Dionysus in the mystery religions brought the real back to its hidden soul (PO, 239), the Pauline retrieval of the esoteric dimension is the revelation of the present as grounded not in any particular thing or event, but abysmally rooted in eternally hidden depths. Not only does Paul challenge the Petrine Church, he foreshadows the power of the Protestant revolt. "In Paul lives the

Stuttgart-Augsburg 1856-I86I; Schellings Werke: Nach der Originalausgabe in neuer Anordnung, Hrsg. M. Schröter, Munich 1927. 
dialectical, limber, scientific, confrontational principle" (PO, 3I7). It is, however, only a "transitional form" (PO, 32O), although "Paul's lightening strikes of genius [...] liberated the Church from a blind unity" (po, 322) and revealed the ideal within the real. There is no getting around Luther-he was the Pauline Rubicon.

Still, for Schelling, he is not the final word because in revealing the mystery of the ground, he had not yet unleashed its creativity. Yes, the deus absconditus destroys all images in an absolute iconoclasm, but it is also the dark heart of the ceaseless creativity of the divine and human imagination.

If Schelling were to "build a Church in our time," he "would consecrate it to Saint John the Evangelist. But sooner or later there will be a Church in which the three above named apostles are united; this Church will then be the true pantheon of Christian Church history" (U, 708)! The Church to come is the Church not merely in the future but of the future, that is, a church that liberates time and activates the creativity of the future, a church of the whole of time (the infinite depth of the past, the mystery of the present, and the unprethinkable future); in a word, philosophical religion espouses the Church of the $\mathrm{A}^{3}$. John is the "apostle of the future" (PO, 3I7): "One is not merely an apostle in the time in which one lives" and John was "actually not the apostle for his time." Paul would first have to come, but the "Lord loved" John, "that is, in him he knew himself" (U, 703). The Johanine Church, the church for everyone and everything-for all things human and for the mysterious creativity of the earth itself-is the "being everything in everything of God" (U, 708-709), a "theism that contains within itself the entire economy of God" (U, 709). This religion not only does not exclude anything, but it includes everything as alive, where "everything has its inner process for itself" ( $\mathrm{U}, 7 \mathrm{IO})$. This is religion beyond Petrine empire (the imposition of external forms of religion) and Pauline revolt (the recovery of the esoteric soul of religion). This is the mysterious and creative life of "a revealed God, not an abstract idol" (PO, 324).

Schelling and Luther? Both harbor the latency of the enigma of the past that is always still to come and to create anew. 


\section{BiBLIOGRAPHY}

Breton S., The Word and the Cross, trans. J. Porter, New York 2002.

Laughland J., Schelling versus Hegel: From German Idealism to Christian Metaphysics, Aldershot-Burlington 2007.

Luther M., Concordia: The Lutheran Confessions - A Reader's Edition of the Book of Concord, second edition, ed. P. T. McCain, Saint Louis 2006.

Mjaaland M. T., The Hidden God: Luther, Philosophy, and Political Theology, Bloomington-Indianapolis 2016.

Schelling F. W. J., Initia Philosophia Universa (I82O-2I), Hrsg. H. Fuhrmans, Bonn 1969.

Schelling F. W. J., Philosophie der Offenbarung $1841 / 42$ [The Paulus Nachschrift], second, expanded edition, Hrsg. M. Frank, Frankfurt am Main I993.

Schelling F. W. J., Schellings Sämtliche Werke, Hrsg. K. F. A. Schelling, Stuttgart-Augsburg 1856-I86r.

Schelling F. W. J., Schellings Werke: Nach der Originalausgabe in neuer Anordnung, Hrsg. M. Schröter, Munich 1927.

Schelling F. W. J., Urfassung der Philosophie der Offenbarung, two volumes, Hrsg. W. E. Ehrhardt, Hamburg 1992.

Schelling F. W. J., Die Weltalter in den Urfassungen von I8II und I8I3 (Nachlaßband), Hrsg. M. Schröter, Munich 1946. 